\title{
KOMODIFIKASI AGAMA DALAM GERAKAN MAJLIS TAFSIR AL-QUR'AN (MTA) DI SURAKARTA
}

\author{
Zaki Faddad Syarif Zain \\ UIN Raden Fatah Palembang \\ Email: zakifaddad_uin@radenfatah.ac.id \\ Anisatul Mardiah \\ UIN Raden Fatah Palembang \\ Email: anisatulmardiah_uin@radenfatah.ac.id
}

\begin{abstract}
This paper aims to describe the process of religious commodification within Majlis Tafsir Al-Qur'an (MTA) in Surakarta. The teaching and practices of MTA (such as the doctrine of salvation, leadership and brotherhood, and the practice of pengajian) have effectively constructed social belonging among its members. It represents the production of social identity, loyalty, and solidarity. Besides, the charisma of its leader, Ahmad Sukino, has become a center of social appeal. Social belonging and charisma become influential elements for the MTA members. One of the MTA compelling-doctrines is the doctrine of jihad harta. It occurs through mobilizing the contribution of MTA members and commodifying pengajian. Referring to Kitiarsa (2010), there are at least two reasons behind this religious commodification: commodity and market. MTA monetizes religion-based objects, such as brochures, books, and videos. Pengajian becomes a market where the process of commodification follows.
\end{abstract}

[Tulisan ini membahas proses komodifikasi agama dalam gerakan MTA (Majlis Tafsir Al-Qur'an) di Surakarta. Ajaran 
dan praktek MTA (seperti ajaran keseselamatan, imamah/jemaah, dan pengajian dengan segala aturannya) diyakini efektif untuk membentuk sistem keterikatan sosial (social belonging). Hal ini dibuktikan dengan terbentuknya identitas sosial, loyalitas, dan solidaritas antar anggota. Selain itu, kharisma pemimpin MTA, Ahmad Sukino, menjadi daya tarik tersendiri. Keterikatan sosial dan kharisma adalah motor penggerak bagi warga MTA. Salah satu yang ajaran yang ditanamkan dalam pengajian itu adalah doktrin "jihad harta", dengan cara memobilisasi donasi anggota dan memodifikasi arena pengajian sebagai pasar untuk menjual produk. Merujuk Kitiarsa (2010), terdapat dua syarat terjadinya komodifikasi agama dalam tubuh MTA, yakni komoditas dan pasar. MTA memoneterisasi hal-hal yang berhubungan dengan keagamaan, mulai dari brosur, buku-buku agama, hingga vcd atau mp3 pengajian yang dijual sebagai bahan ajar. Pengajian menjelma menjadi pasar, karena dalam pengajian inilah proses monetarisasi, baik berupa produk barang maupun jasa massif, dilakukan.]

Keywords: Majlis Tafsir Al-Qur'an, religious doctrine, social belonging, market, and commodification.

\section{Pendahuluan}

Di tingkat nasional, mungkin hanya laskar 212 yang berani "menantang" Banser dan NU (Nahdhatul Ulama) secara terbuka karena perbedaan politik. Namun di tingkat lokal, ada satu organisasi yang sering bikin marah Banser, bahkan mungkin FPI (Front Pembela Islam), yang bernama Yayasan Majlis Tafsir AlQur'an (MTA). Organisasi yang berpusat di Surakarta ini seringkali terlibat konflik dengan kelompok tradisionalis, utamanya di pedesaan karena perbedaan masalah furüiyyah. Menurut Jinan ${ }^{1}$ gerakan yang berpusat di Surakarta itu dapat dikategorisasikan sebagai gerakan puritan yang lebih banyak mendapat pengikut di pedesaan dibandingkan perkotaan. Hal ini menarik, mengingat

\footnotetext{
${ }^{1}$ Mutahharun Jinan, "Penetrasi Islam Puritan di Pedesaan: Kajian tentang Pola Kepengikutan Warga Majlis Tafsir Al-qur'an," Profetika: Jurnal Studi Islam, 14, 2, (2013), 105-124.
} 
desa dianggap sebagai basis keislaman tradisionalis, sementara gerakan puritan cenderung diminati masyarakat urban. ${ }^{2}$

Perpecahan ini terjadi karena di satu sisi MTA seringkali menentang ritual keagamaan yang popular di masyarakat, seperti yasinan, tablilan, bancaan, dan lainnya. Majlis ini dengan tegas menolak apa yang disebutnya sebagai takhayul, bid'ah dan khurafat. Kritik-kritik MTA disampaikan secara gamblang, terbuka, disiarkan melalui radio-radio dan pengajian umum, dan menyasar kelompok Islam tradisionalis, utamanya NU. Berdasarkan penelitian Nihlatul Laili (2016) $)^{3}$ konflik antara NU dan MTA hingga tahun 2013 telah terjadi setidaknya di Sragen, Blora, Purworejo dan Kudus.

Konflik di Purworejo pada tahun 2011 cukup menarik. Ma'rifah dan Asroni (2013) ${ }^{4}$ mengungkapkan bahwa dalam penyelesaian konflik, pihak MTA meminta maaf dan berjanji akan mengevaluasi metode dakwah mereka agar tidak provokatif. Meski begitu, konflik yang disebabkan metode dakwah MTA tersebut belum berakhir. Berdasarkan penelusuran daring, konflik terjadi di Kecamatan Adimulyo, Banyumas, pada akhir tahun 2018 hingga 2019. Warga sekitar menolak adanya pengaiian MTA. Kepala daerah (Camat) di daerah itu bahkan mengkoordinir warga agar menolak keberadaan MTA. Tidak hanya di Jawa Tengah, penolakan terhadap MTA juga terjadi di Jawa Timur, seperti Nganjuk (2012), Bojonegoro (2013), Sidoarjo dan Gresik (2012), Magetan (2016), serta di Provinsi Yogyakarta, tepatnya di Gunung Kidul (2016). Tulisan ini ingin menjawab mengapa konflik tersebut masih terus berlangsung dan mengapa gerakan ini masih terus memproduksi wacana keagamaan yang provokatif terhadap kelompok Islam tradisionalis.

\footnotetext{
2 Joseph Tamney, "Moderization and Religious Purification: Islam in Indonesia," Review of Religious Reseach, Vol 22, No 2, (1980), 207-218.

3 Nihlatul Laili, "Majlis Tafsir Al-Qur'an (MTA) vs Nahdlatul Ulama (NU): Konflik Sosial Keagamaan Masyarakat Islam Jawa Tengah Tahun 1990-2013 (Yogyakarta: Disertasi doktoral -Universitas Gadjah Mada, 2016).

4 Indriyani Ma'rifah dan Ahmad Asroni, "Berebut Ladang Dakwah pada Masyarakat Muslim Jawa: Studi Kasus terhadap Konflik Majelis Tafsir AlQur'an (MTA) dan Nahdlatul Ulama (NU) di Kabupaten Purworejo," Jurnal Dakwah, Vol 14, No 2, (2013), 213-234.
} 
Selain itu, sudah banyak juga studi yang membahas MTA dari sudut pandang teologi ${ }^{5}$ dan budaya gerakan. ${ }^{6}$ Dari sudut pandang budaya gerakan, Haryanto membahas transformasi MTA di Surakarta, yang kental dengan budaya Jawanya, ke daerah-daerah yang lebih bercorak puritan. Ia berargumen bahwa telah terjadi proses perubahan sosial, perkembangan pendidikan, dan rasionalisasi budaya.

Studi mengenai gerakan MTA yang paling mendekati penelitian ini adalah studi yang dilakukan oleh Muhsin dan Gufron (2018). ${ }^{7}$ Mereka menjelaskan bahwa MTA memiliki agenda tersendiri di balik gerakan purifikasinya, menggunakan teori Gerakan Sosial McAdam (1996), ${ }^{8}$ yakni (1) memanfaatkan dukungan secara politik dari tokoh nasional melalui program Silatnas dan Pengajian Minggu Pagi; (2) memiliki kemampuan dalam memobilisasi sumber daya seperti ajaran, kaderisasi, dan amal usaha, dan (3) memiliki kemampuan framing bahwa MTA focus pada upaya mengobati persoalan-persoalan sosial. Muhsin dan Gufron meneguhkan mengapa MTA mampu mempertahankan model dakwahnya yang kontroversial, melalui koneksi politik dengan pejabat pemerintahan, partai politik, maupun agamawan. Lebih dari itu, MTA memiliki sumber daya manusia dan finansial. Sumber daya itu membuat MTA memiliki daya tawar yang cukup kuat secara politik.

Berbeda dari studi di atas, penelitian ini mengambil sudut pandang lain dengan cara melihat hubungan antara konflik dan

5 Muhammad Asif, "Sejarah Tafsir MTA (Majlis Tafsir Al-Qur'an)," Al-Itqan Jurnal Studi Al-qur'an, Vol 1, No 1, (2015); Imam Qusthalaani, "Analisis Penafsiran Ayat Hisab Rukyat Menurut Majlis Tafsir Al-qur'an” (Semarang: Disertasi doktoral-UIN Walisongo, 2016); M. Alfatih Suryadilaga, "Majlis Tafsir Al-Qur'an dan Keberagamaan di Indonesia: Studi tentang Peran dan Kedudukan Hadis Menurut MTA," Masyarakat Indonesia, Vol 41, No 1, (2016), 57-73.

6 Joko Tri Haryanto, "Relationship, Transformation and Adaptation of The Traditionalists Against Puritanism in Surakarta Indonesia," Analisa: Journal of Social Science and Religion, Vol 22, No 2, (2015), 239-253.

7 Ilyya Muhsindan Muhammad Ghufron, "Geliat Puritanisme Islam di Indonesia: Menyibak Tabir di Balik Gerakan Majelis Tafsir Al-Qur'an (MTA) dalam Perspektif Sosiologis," Inferensi: Jurnal Penelitian Sosial Keagamaan, Vol 12, No 1, (2018), 213-238.

8 Doug McAdam et. al, Comparative Perspectives on Social Movements: Political Opportunities, Mobilizing Structures, and Cultural Framings (Cambridge: Cambridge University Press, 1996). 
pembentukan loyalitas serta solidaritas anggota. Hal ini memungkinkan MTA memobilisasi donasi dari para anggota. Penelitian ini mencoba menjelaskan mengapa konflik antara kelompok Islam tradisionalis dengan MTA masih berlangsung. Tulisan ini bermaksud mengaitkan identitas sosial pengikut MTA yang dibentuk melalui indoktrinasi dengan resistensi mereka terhadap tradisi lokal. Penguatan identitas ini menumbuhkan loyalitas dan solidaritas di antara warga MTA, sehingga mereka mampu bertahan secara berkelompok meskipun mendapatkan banyak penentangan, terutama terkait metode dakwah mereka. Loyalitas seperti ini memungkinkan organisasi MTA untuk memobilisasi para pengikut demi keuntungan ekonomi.

\section{Sekilas tentang MTA}

MTA didirikan oleh Abdullah Thufail Saputro. Ia lahir di Pacitan Jawa Timur pada tanggal 19 September 1927. Pengetahuan agama Abdullah Thufail mulanya diterima dari ayahnya yang dikenal sebagai seorang pemimpin spiritual tarekat Naqsyabandiyah. Abdullah Thufail kecil bersekolah di sekolahsekolah modern seperti Taman Siswa dan Muhammadiyah. Selain itu, Abdullah Thufail juga pernah belajar kitab-kitab Islam klasik di pondok pesantren Termas, Pacitan dan pondok Popongan, Delanggu, Klaten. Ia fasih dan menguasai bahasa Arab serta bisa membaca kitab-kitab Islam klasik, seperti tafsir, hadis, dan kitabkitab fikih. ${ }^{9}$ Setelah lulus Sekolah Dasar, Abdullah Thufail melanjutkan pendidikannya ke SMP dan SMA di Al-Irsyad, Solo.

Abdullah Thufail kemudian melanjutkan studi di Universitas Cokroaminoto Surakarta, namun tidak tamat. Ia lebih memilih meneruskan usaha Ayahnya berjualan mutiara sambil berdakwah. Diceritakan, bahwa Abdullah Thufail pernah bergabung sebagai anggota Dewan Dakwah Islam (DDI) di Bali. Organsasi ini didirikan oleh Muhammad Natsir setelah tidak lagi aktif berpolitik pada tahun 1960-an. Natsir mendirikan DDI setelah dibubarkannya Masyumi sebagai partai politik. Organisasi ini kental dengan ideologi pemurnian Islam dalam agenda dakwah yang diusungnya. Kiprah Abdullah Thufail di gerakan-gerakan itulah

\footnotetext{
9 Widodo, "Yayasan Majlis Tafsir Alquran (MTA) Surakarta Tahun 1972-1998: Studi Tentang Gerakan Modern Islam di Surakarta," (Surakarta: Skripsi, Fakultas Sastra Universitas Sebelas Maret Surakarta, 1998), 24.
} 
yang nampaknya sangat berpengaruh membentuk ide pemurnian Islam.

Pada tahun 1955-1960, ia bedagang sambil berdakwah keliling Jawa. Pada tahun 1960-1965 ia berdagang hingga keluar Jawa, seperti Sumatera, Kalimantan, Sulawesi, Bali dan Nusa Tenggara. Di Bali, ia sempat memiliki sebuah toko permata yang besar sebelum akhirnya bangkrut. Setelah kejadian itu ia pindah dan menetap di Solo, meneruskan komitmennya untuk berdakwah pada tahun 1965. ${ }^{10}$ Di Solo inilah awal mula Abdullah Thufail berkiprah dalam kegiatan dakwah dan membangun organisasi yang nanti membuatnya menjadi ulama terkemuka.

Tahun 1965, ketika terjadi pemberontakan G30S/PKI, Abdullah Thufail bergabung dengan barisan pemuda untuk menumpas Partai Komunis Indonesia (PKI). Konon karena kedekatannya dengan Jendral Sarwo Edi Wibowo, ia ditunjuk sebagai ketua Koordinasi Kesatuan Pemuda Indonesia (KPPI) cabang Surakarta periode 1966-1967. Organisasi ini didirikan oleh pemerintah untuk menumpas PKI. Pada saat munculnya Supersemar 1966, beliau mengirim "Buku Putih" kepada Jendral Soeharto yang isinya menolak kepemimpinan Presiden Soekarno dan menuntut dibubarkannya PKI. ${ }^{11}$ Dari sinilah ia mulai dikenal oleh masyarakat Solo, terutama di kalangan gerakan Islam politik.

Di Solo, Abdullah Thufail memulai aktifitas dakwahnya di Kelurahan Semanggi, Kecamatan Pasar Kliwon, sebuah kawasan yang terletak di sebelah timur Kraton Surakarta. Abdullah Thufail dikenal sebagai seorang ulama yang sederhana dan seorang pendakwah kharismatik. Dia pernah memberikan seluruh tabungannya untuk membeli tanah untuk pembangunan gedung dakwah. Selain itu, Abdullah Thufail dikenal sebagai orator yang handal, suaranya lantang dan lugas dalam menyampaikan ceramah. Abdullah Thufail sangat menginginkan persatuan Islam.

Pada awal tahun 1972, Abdullah berinisiatif mengundang beberapa organisasi Islam di Surakarta. Tujuannya membentuk persatuan besar umat Islam. Organisasi yang diundang antara lain: Muhammadiyah, Nahdlatul Ulama (NU) dan PSII. Namun

\footnotetext{
${ }^{10}$ Ibid., 28.

11 Ibid., 29-30
} 
usahanya tidak membuahkan hasil. Setiap organisasi Islam memiliki agenda yang berbeda. Organisasi-organisasi itu menolak gagasannya. Meskipun gagasannya gagal diwujudkan, Abdullah mengusahakan kelompok dakwah dengan mengajak $M$ Iksan sebagai sekretaris dan Abdullah Sungkar sebagai bendahara. Di sendiri bertindak sebagai ketua organisasi. Dari sinilah, pada tanggal 19 September 1972, ia mendirikan suatu kelompok pengajian yang awalnya hanya memiliki tujuh anggota.

Pembentukan kelompok ini dipengaruhi oleh konteks politik pada masa itu, yakni sebagai respons atas kegagalan dan lemahnya Islam Politik setelah pemilu 1971. Abdullah mencoba merumuskan berbagai persoalan yang sedang dihadapi umat Islam sebagai berikut. Pertama, masalah umat Islam Indonesia yang terbelakang. Kedua, umat Islam yang terpecah menjadi golongangolongan dan saling menganggap diri mereka paling benar. Menurutnya, problem keterbelakangan umat Islam disebabkan oleh ketidakmengertian umat Islam terhadap Alquran. Begitu juga problem perpecahan umat Islam, disebabkan kurangnya pemahaman terhadap makna Alquran. Oleh sebab itu, Abdullah Thufail mengajak umat Islam untuk kembali memahami Alquran.

Abdullah Thufail tidak berhenti memperjuangkan gagasannya untuk mempersatukan kelompok-kelompok Islam. Pengajian gelombang kedua dibuka secara resmi pada tanggal 16 Desember 1972. Kegiatan itu disebarluaskan melalui pemancar radio yang diberi nama RADIS (Radio Dakwah Islam Surakarta) yang didirikannya bersama Abdullah Sungkar. Pembukaan itu dihadiri oleh berbagai elemen agama di Solo. Abdullah Thufail meminta tokoh-tokoh dari tiap elemen gerakan Islam di Solo untuk mengisi pengajian di sana.

Pada masa awal Orde Baru, organisasi Islam ditekan untuk mengakui Pancasila sebagai asas tunggal. Akibatnya, muncul fragmentasi antara kelompok Islam yang menolak dan kelompok yang menerima asas tunggal. Abdullah Thufail memilih bersikap akomodatif dengan pemerintah saat itu. Inilah yang menyebabkan pertentangan antara dirinya dengan Abdullah Sungkar. Abdullah Sungkar berbeda paham mengenai penerimaan asas tunggal. Keduanya lantas berjalan sendiri-sendiri: Abdullah Sungkar mendirikan faksinya yang kemudian berafiliasi dengan gerakan Darul Islam pimpinan Ajengan Marzuki dan bersikap resisten 
terhadap pemerintah. ${ }^{12}$

Untuk meyakinkan pemerintah bahwa pengajiannya tidak bertentangan dengan penguasa, Abdullah Thufail melembagakan pengajiannya dalam bentuk yayasan pada 23 Januari 1974 dan diberi nama Majlis Tafsir Al-Qur'an (MTA). MTA resmi didirikan dengan berasaskan Islam dan berlandaskan Pancasila dan UUD 1945. Dalam peresmian gedung dakwahnya, ia mengundang Komandan Resimen 074 Surakarta, Letkol Prayitno, dan sejumlah pejabat teras Pemerintah Surakarta. Sementara peresmian gedung itu sendiri dilakukan oleh K.H Ali Darokah, ketua MUI pada saat itu. $^{13}$

Sepeninggal Abdullah Thufail tahun 1992, beberapa petinggi MTA berkumpul untuk bermusyawarah menunjuk penggantinya. Hasil Musyawarah tersebut menetapkan Ahmad Sukino sebagai pemimpin tertinggi organisasi atau Imam MTA hingga kini. Sukino lahir di Gawok Sukoharjo Jawa Tengah. Pendidikan dasar dan menengahnya diselesaikan di Sragen. Sedangkan pendidikan menengahnya adalah dari Pendidikan Guru Agama Surakarta (PGA). Setemat dari PGA, Sukino mengabdi di SD Muhammadiyah Makamhaji hingga diangkat menjadi PNS. Sebelum bergabung dengan MTA, ia aktif di Pemuda Muhammadiyah Surakarta. Sambil mengajar, ia melanjutkan studi sarjana di Fakultas Tarbiyah Universitas Muhammadiyah Surakarta. Seusai meraih gelar sarjana, Sukino bergabung dengan MTA. Ia dikenal sebagai murid paling setia dari Abdullah Thufail. Sukino pernah dikirim ke Pakistan oleh Abdullah Thufail untuk belajar berdakwah bersama Jemaah Tabligh.

Sama seperti pendahulunya, Sukino dikenal sebagai seorang penceramah ulung. Sifat-sifat itulah yang menjadi daya tarik personalnya sebagai Imam MTA. Gaya bicaranya lugas dan tegas dalam menjawab pertanyaan. Pada masa kepemimpinan Ahmad Sukino, tujuan pemurnian dipertegas kembali dengan upaya pembersihan agama dari unsur budaya lokal secara simbolik. Simbolisasi dilakukan dengan cara penyerahan jimat dari para anggota pengajian MTA yang menyatakan diri "bertobat" dan tidak

\footnotetext{
12 Fajar Riza U1 Haq, "Islam Sebagai Gerakan Sosial, Studi atas Jama'ah AlIslam Gumuk Surakarta,” (Yogyakarta: MA Tesis-CRCS UGM, 2008).

${ }^{13}$ Widodo, "Yayasan Majlis Tafsir Al-Qur'an...," 36.
} 
lagi percaya pada jimat, karena dianggap sebagai kesyirikan. Jimat itu oleh pengurus MTA kemudian dipajang dalam museum yang terletak di dalam gedung MTA Pusat. Jimat yang biasanya dikesankan angker, bagi MTA hanyalah pajangan. Keberadaan museum jimat tidak lain adalah meyakinkan masyarakat untuk menjauhkan dari sifat takhayul dan syirik (menyekutukan Tuhan). Simbolisasi juga dilakukan dengan pembangunan Gedung MTA Pusat yang berada persis di depan Kraton Mangkunegaran di mana selalu diadakan ritual-ritual, seperti Kirab Pusaka Keraton. MTA sangat menentangnya ritual semacam ini.

Di bawah kepemimpinan Ahman Sukino, MTA berupaya memperluas jaringan terutama mendekatkan dirinya terhadap berbagai komunitas Islam dan memilih tidak berafiliasi pada partai politik tertentu. MTA kini tidak lagi berafiliasi pada Golkar. Namun begitu, bukan berarti MTA tidak berpolitik. MTA berupaya memperoleh dukungan baik dari pihak sipil dan negara. Dukungan sipil dilakukan dengan cara menarik beberapa tokoh-tokoh agama untuk mengisi pengajian MTA.

\section{Doktrin MTA}

Untuk melihat bagaimana MTA membentuk loyalitas jemaah, penting melihatnya dari ajaran atau doktrin yang membentuk identitas sosial mereka. Dari sisi keagamaan, MTA sependapat dengan kelompok pemurnian Islam, yakni upaya purifikasi agama dari kepercayaan lokal, dan berselisih pendapat dengan kelompok tradisionalis yang pengamalan ibadahnya dianggap tidak berdasar Alquran dan hadis. MTA memiliki tiga doktrin: kembali kepada Alquran dan Sunnah, imamah dan jemaah, serta jihad harta. Menariknya, ketiga doktrin tersebut memiliki perbedaan dengan gerakan puritan lain, seperti Muhammadiyah dan Persis, dan lebih dekat dengan Islam Jemaah yang saat ini dikenal dengan Lembaga Dakwah Islam Indonesia (LDII). Doktrin ini tidak hanya bersifat ideologis, tapi juga strategis. Selain mengusung agenda pemurnian agama, MTA juga berupaya mempertahankan sistem internal ideologi, kepemimpinan, mengembangkan infrastruktur, serta menjaga keberlangsungan gerakan menghadapi kondisieksternal.

\section{Mengaji Alquran dan Hadis}

Kritik MTA terhadap kelompok Islam tradisionalis setidaknya 
focus pada dua hal: kedudukan Alquran dan hadis dan ritual keagamaan yang tidak didasarkan pada keduanya. Menurut MTA, kandungan Alquran sudah lengkap, meliputi ilmu akidah, syari'ah, ibadah, dan akhlak. Dalam mempelajari Alquran, MTA menggunakan tafsir Alquran dan terjemahan Departemen Agama. Hal tersebut bisa dilihat dari ceramah-ceramah Sukino yang selalu menggunakan kitab tafsir sebagai rujukan utama. Para peserta pengajian MTA juga selalu membawa Alquran terjemahan serta menyimak ayat-ayat yang dibacakan oleh penceramah. Penggunaan tafsir Alquran dari Kementrian Agama, menurut Medi (sekretaris MTA), secara praktis dimaksudkan untuk mempermudah setiap orang mempelajari Alquran, karena tafsir itu mudah didapatkan. Selain itu, MTA ingin menekankan bahwa pada prinsipnya Alquran itu mudah dipelajari. ${ }^{14}$ Namun demikian, ada tujuan strategis dari penggunaan tafsir Alquran Departemen Agama, yakni sikap akomodatif MTA terhadap Pemerintah.

MTA di satu sisi mengecam taklid, namun di sisi lain membatasi ijtihad. Mereka menolak penetapan hukum yang didasarkan pada mazhab ataupun ulama tertentu. Dalam Bahasa keseharian mereka berkata: "Beragama itu tidak usah pakai makelar." Menurut MTA, cara beragama yang paling baik dan selamat adalah dengan langsung mengutip Alquran dan Hadis, karena kedua sumber tersebut telah menjelaskan agama secara lengkap. Namun demikina, MTA membatasi pelaksanaan ijtihad. Bagi MTA, persoalan agama Islam sudah selesai pada masa Nabi Muhammad saw., dengan adanya Alquran dan Hadis. Dilihat dari sudut pandang imamah dalam organisasi MTA, seluruh keputusan dan fatwa agama yang dikeluarkan gerakan ini bersifat eksklusif dan menjadi otoritas pimpinan tertinggi.

Praktik agama yang dilakukan berdasar tradisi atau kebiasaan disebut MTA sebagai bid'ah, suatu yang baru dalam agama. Amalan yang tidak ada tuntunannya dalam Alquran dan Hadis. MTA percaya bahwa bid'ah berlaku untuk urusan amal ibadah kepada Allah swt., karena segala sesuatu sudah dituntunkan oleh Nabi Muhammad melalui hadis-hadis sahih. Contoh amalan yang dianggap bid'ah, misalnya, adalah yasinan dan tablilan. Amalan ini ditolak karena dianggap hadis-hadis yang menjelaskannya bersifat daif (tidak terpercaya).

MTA juga mengecam kepercayaan terhadap khurafat atau takhayul, yakni mempercayai kekuatan selain Allah. Khurafat dan

${ }^{14}$ Wawancara dengan Sumedi, sekretaris MTA Pusat, September 2017. 
takhayul membuat manusia menyekutukan Allah dan itu dosa besar. Praktik perdukunan yang menggunakan mantra atau jimat dan memberi kemenyan di tempat yang dianggap keramat adalah contoh dari perbuatan khurafat. Penolakan MTA terhadap masalah ini diwujudkan dengan membangun majlis MTA di dekat tempat yang dianggap angker dan mendirikan Museum Jimat.

\section{Doktrin Jemaah, Imamah, dan Baiat}

Dalam pergerakannya, MTA memiliki prinsip imamah dan baiat. Konsep ini diperkenalkan pertama kali oleh Abdullah Thufail Saputro, pendiri gerakan. Setiap anggota MTA harus memahami akidah imamah sebelum ia melaksanakan baiat (sumpah setia) terhadap imam dan jemaah. MTA memahami jemaah sebagai "persatuan", sebagai lawan kata dari firqah (golongan). Sementara Imam dianggap sebagai pemimpin tertinggi yang harus ditaati dan diikuti. Janji taat kepada sang Imam dan kepada jemaah dilakukan melalui mekanisme baiat.

Hadis yang mengatakan bahwa umat Islam akan terpecah menjadi 73 golongan, 72 golongan akan masuk neraka sementara 1 golongan akan masuk surga, menjadi dalil dan legitimasi MTA terkait dengan keyakinan al-Jamäah. Imam adalah pimpinan yang harus ditaati dalam suatu jemaah, berdasarkan pada kedudukan Nabi sebagai imam yang diteruskan oleh para khalifah sebagai amirul mukminin. Dalam keyakinan MTA, seorang imam atau pemimpin adalah orang yang menguasai agama, memahami hukum Islam menurut Alquran dan hadis sahih, serta baik budi pekertinya. Setiap anggota MTA harus menaati dan menuruti apa yang diperintahkan sang imam, selama ia tidak keluar dari ajaran Alquran dan Sunnah. Setelah melakukan baiat, seseorang tidak boleh keluar dari jemaah.

Pada awalnya, Abdullah Thufail mengenalkan doktrin imāmah dan jamäah untuk mewujudkan persatuan Islam. Pada perkembangannya, doktrin ini hanya diperuntukkan bagi anggota pengajian khususi, yakni pengajian khusus yang dipersiapkan untuk mendidik calon leader MTA. Doktrin ini tidak populer di kalangan Islam Sunni dan hanya dikenal dalam lingkungan Syiah dan Islam Politik. Sementara itu, persepsi publik mengenai Islam Jemaah masih terkait dengan gerakan golongan Syiah yang disesatkan oleh MUI tahun 1984 atau Darul Hadis yang dianggap sesat pada 1978. 
Oleh sebab itu tidak mengherankan jika doktrin ini tidak muncul di kalangan anggota MTA tingkat bawah.

Konsep imamah dan Jemaah kemudian diturunkan menjadi dua model. Pertama, model kepemimpinan struktural yang bersifat hierarkis-sentralistis. Al-Ustadz dalam MTA memiliki posisi sentral. Ia memiliki otoritas tertinggi dalam mengambil kebijakan. Meskipun ada devisi kerja secara wilayah namun kedudukan setiap devisi tidaklah otonom. Segala keputusan ada di tangan Al-Ustad. Setiap hari Minggu selepas Pengajian Minggu Pagi, seluruh pengurus MTA dari berbagai level berkumpul untuk mendapatkan pengarahan dari Al-Ustad.

MTA membagi organisasinya dalam tiga level, berdasarkan wilayah kerja, yakni cabang (setingkat kecamatan), perwakilan (setingkat kabupaten/kota madya), dan pusat. Untuk para pengurus cabang dan perwakilan, mereka adalah representasi dari warga MTA di wilayahnya masing-masing, atau menjadi mediator antara warga dengan Al-Ustad Ahmad Sukino. Meskipun MTA menerapkan struktur yang hierarkhis dan sentralistis, namun di tingkat cabang dan perwakilan tidak menutup kemungkinan untuk memiliki inisiatif sendiri dalam kebijakannya. Jika dirasa itu baik bagi gerakan, maka pengurus masing-masing wilayah dapat mengambil kebijakannya sendiri.

MTA tidak mengenal adanya suksesi kepemimpinan pengurus. Mereka melaksanakan tugasnya sebagai pengurus berdasarkan kemampuan diri masing-masing. Jika tidak mampu lagi untuk melaksanakan tugas sebagai pengurus, karena alasan kesehatan atau yang lain, mereka dapat mengundurkan diri dan digantikan orang lain. Biasanya pengurus cabang adalah mereka yang menjadi pelopor berdirinya cabang. Begitu juga dengan pengurus perwakilan. Kepengurusan dalam MTA bersifat pengabdian hidup. Mereka membakukan norma bagi para pengurus untuk loyal kepada MTA. Jika tidak loyal, maka Al-Ustad dapat mencabut status kepengurusan seseorang, bahkan bisa dikeluarkan dari organisasi MTA. Loyalitas pengurus ditunjukkan dengan tidak bolehnya mereka merangkap organisasi lain selain MTA dan tidak boleh mengundang pengajar dalam sebuah pengajian dari luar MTA. Para pengurus MTA untuk level pusat dan perwakilan adalah anggota pengajian khusus yang dibaiat oleh Al-Ustad. 
Kedua, model pengaiian beserta aturannya. Para peserta pengajian khusus harus melalui mekanisme baiat dan selanjutnya mendapat pengajaran langsung dari Al-Ustad. Sementara pengajian cabang dipimpin oleh para guru daerah yang sebagian besar dari mereka adalah anggota pengajian khususi. Guru daerah itu berperan sebagai perantara antara Ustad dan jemaah MTA. Meskipun model baiat hanya diterapkan kepada para siswa pengajian khususi, namun pada pengajian cabang juga diterapkan sistem absensi dalam pengajian. Pengajian adalah syarat wajib untuk masuk dalam keanggotaan MTA. Ada aturan ketat terkait keanggotaan MTA, semisal "jika seorang anggota tidak hadir tiga kali berturut-turut tanpa alasan yang jelas dalam pengajian, maka ia akan dikeluarkan dari keanggotaan."

\section{Jihad Harta}

Menurut Abdullah Thufail, jïhäd fì sabililläh adalah jalan menuju kebahagiaan dunia dan akhirat. Allah menggambarkannya sebagai suatu deklarasi perjanjian antara Dia dengan para pejuang: Allah membeli jiwa dan harta kaum mukminin dengan imbalan surga. Menurutnya, Jihad harus dimulai dengan melawan hawa nafsu. Hawa nafsu manusia salah satunya adalah ketamakan yakni kecintaan yang berlebihan terhadap harta yang dimiliki. Padahal, harta adalah sumber kesombongan. Jihad diartikan sebagai upaya untuk melawan keserakahan dan kesombongan. Implementasi jihad melawan hawa nafsu menurut MTA adalah "jihad harta" dengan mendonasikan sebagian hartanya melalui zakat (bersifat wajib), infak, dan șadaqah (sukarela) untuk kepentingan dakwah.

Doktrin MTA menyatakan bahwa menyisihkan harta di jalan Allah tidak akan membuat seseorang menjadi miskin, justru harta itu akan bertambah dan mendapat pahala berlipat. Konsep donasi dalam MTA berupa kewajiban untuk menyisihkan hasil usahanya sebesar 2,5\%. Dari pemahaman ini, MTA memobilisasi pengikutnya untuk melakukan donasi demi keberlangsungan gerakan. Dari merekalah sumber dana MTA didapatkan untuk membangun seluruh infrastruktur organisasi, termasuk gedung Pusat MTA, majlis pengajian di setiap cabang, MTA TV, dan radio Persada FM. 


\section{Konstruksi Identitas Warga MTA melalui Pengajian dan Majlis}

Keanggotaan warga MTA diidentifikasi melalui pengajian di dalam majlis. Di majlis inilah warga MTA meneguhkan keanggotaaanya dengan mengikuti rutinitas pengajian beserta aturan-aturan keanggotaannya, terutama menyangkut presensi kehadiran. Ketidakhadiran seorang warga MTA dalam suatu pengaiian tidak mengancam dikeluarkannya sebagai anggota, namun ada semacam sanksi sosial. Guru Daerah selalu menyindir warga MTA yang tidak datang pada saat pengajian hanya karena alasan pribadi yang menurutnya tidak jelas. Ia selalu memperingatkan pentingnya suatu pengajian sebagai pengabdian seseorang kepada Tuhan. Oleh karena itu, bagi seorang warga MTA tidak ada alasan untuk tidak pergi mengaji hanya untuk kepentingan duniawi. Peringatan tidak hanya datang dari Guru Daerah namun juga dari peserta yang lain. Informan bernama Sumasno dari cabang di Boyolali mengatakan:

"Mengaji itu tidak boleh kalah dari urusan yang lain. Masak yo pantas orang meninggalkan mengaji hanya buat jagong (menghadiri resepsi pernikahan). Meskipun itu dari salah satu anggota keluarga kita punya hajatan, lebih penting mengaji dari pada datang jagongan. Oleh karena itu, warga MTA biasanya kalo punya hajat tidak menyelenggarakannya pas berbenturan dengan pengajian seperti hari Minggu (Pengajian Minggu Pagi) dan Sabtu (Pengajian Cabang)." 15

Pengajian di majlis menjadi ruang identifikasi keanggotaan seseorang dalam MTA. Rutinitas pengaiian dalam majlis adalah suatu boundary atau batas ruang identifikasi bagi anggota MTA. Warga MTA yang telah secara resmi menjadi anggota cabang tidak diperkenankan hadir dalam ritual-ritual popular dalam masyarakat seperti tablilan, yasinan, dan mauludan. Mereka akan mendapatkan sanksi berupa teguran atau dikeluarkan dari MTA. Warga MTA menunjukkan diri bahwa hanya mereka yang bersungguh-sungguh menegakkan ajaran murni Alquran dan Sunnah. Mereka membedakan dirinya sebagai sekelompok kecil dalam masyarakat

15 Wawancara dengan Sumasno, 2017. 
yang memiliki komitmen itu. Sumasno mengatakan:

"MTA pertama kali hadir di sini dianggap membawa agama baru. Bahkan sampai sekarang. Hal ini karena MTA berperilaku tidak seperti umat Islam pada umumnya yang masih menjalankan tradisi seperti tablilan, yasinan, kenduri, dan sebagainya. Padahal tidak ada tuntunannya (dalam Alquran dan Sunah). Kami dianggap seperti itu yo wes ben (biarkan). Kami yakin dengan apa yang kami lakukan, nanti pertanggung jawabannya ada di Akhirat."

Warga MTA juga mengidentifikasikan gerakannya sebagai "Sang Pencerah", judul sebuah film tentang KH Ahmad Dahlan. Ustad Ahmad Sukino dalam suatu ceramah pernah menjelaskan kesamaan MTA dengan perjuangan KH Ahmad Dahlan tersebut. Ini menggambarkan adanya komitmen untuk mengubah perilaku keberagamaan masyarakat yang belum dapat dilepaskan dari takhayul, bid'ah dan khurafat. Di dalam salah satu adegan film tersebut diceritakan bagaimana Ahmad Dahlan resah terhadap perilaku orang yang memohon pertolongan kepada roh-roh di tempat-tempat keramat. Ilustrasi dalam film tersebut memberikan inspirasi bagi Ahmad Sukino untuk menyemangati para warganya agar tidak surut dalam komitmennya mempromosikan pemahaman mereka dalam menegakkan Alquran dan Sunnah.

Ilustrasi mereka terhadap film Sang Pencerah seolah ingin menunjukkan bahwa kehadiran MTA akan selalu dihadapkan dengan tantangan masyarakat, di samping bersimpati dengan Muhammadiyah sebagai organisasi Islam mainstream terbesar setelah NU. Sumasno mengatakan bahwa tantangan tersebut muncul juga di antara warganya. Ia menyebutkan bahwa salah satu warganya yang berasal dari Desa Geneng Sari, kecamatan Kemusu, Boyolali diboikot oleh penduduk setempat ketika memiliki hajat. Mereka tidak datang saat diberi undangan hajatan dan tidak pula ikut membantu melangsungkan hajatan yang dilakukan. 


\section{Janji Keselamatan}

Pengajian cabang sore itu diisi oleh seorang Guru Daerah bernama Suramto. Ia ditunjuk langsung oleh pimpinan pusat untuk menjadi Guru Daerah tetap di Kemusu, Boyolali. Begitu acara pembuka selesai, ia dipersilakan oleh ketua cabang naik ke mimbar. "Assalamu'alaikum warahmatullahi wabarakatuh. Marilah kita membaca doa pembuka majlis bersama-sama." Ucapnya mengawali pengajian. Setelah itu ia mengucapkan salam dari pimpinan MTA Ahmad Sukino kepada para anggota.

Guru Daerah selalu menyajikan problem keagamaan yang dihadapi melalui perulangan dalam setiap ceramah-ceramahnya, yakni seputar problem keselamatan dan masih banyaknya orang mengaku Islam tapi tidak mengamalkan ajaran Islam yang sesungguhnya. MTA melalui Guru Daerah menawarkan solusi atas persoalan tersebut. Pertama, Alquran dan Hadis sebagai jalan kebenaran menuju keselamatan. Kedua, mengamalkan agama memerlukan ilmu untuk dipelajari. Untuk itu perlu mengkaji Alquran dan Sunnah secara benar, untuk dipraktekkan dalam kehidupan sehari-hari. Ketiga, melalui intensitas kehadiran dalam pengajian dan memperbanyak derma. Dari identifikasi ini dapat ditemukan apa yang menjadi kata kunci dari MTA: selamat, berilmu, mengaji, dan beramal.

Dalam pandangan, MTA perilaku keberagamaan (Islam) yang berdasarkan tradisi lokal tidak akan membawa seseorang ke jalan keselamatan. Bagi mereka, jalan keselamatan adalah apa yang terkandung dalam Alquran dan Sunnah. Membawa ajaran yang benar akan selalu dihadapkan dengan konflik dan penentangan. "Islam itu agama yang asing dan akan kembali asing," begitu ungkapan yang sering terlontar dari Guru Daerah dalam setiap ceramahnya, menukil salah satu Hadis. Dalam diri Warga MTA ditanamkan bahwa keberadaan mereka ibarat suatu kelompok kecil dalam masyarakat yang berupaya mempromosikan pemahaman baru mengenai Islam yang benar.

Guru Daerah mengibaratkan kehadiran MTA seperti halnya kemunculan Islam pada saat awal. Menurutnya, ajaran Islam semakin lama semakin ditinggalkan oleh umat Islam sendiri. Maka upaya mengembalikan Islam pada ajaran murni menjadi asing. Pernyataan ini menjadi penggugah semangat bagi warga MTA untuk keberlangsungan gerakan. Pengajian juga mengarahkan para 
warga untuk melakukan pengawasan antar sesama anggota MTA. Tujuannya, agar para warga MTA terus konsisten pada ajaran yang membawa keselamatan. Meskipun berjenjang, pengajian dalam MTA menjadi suatu kegiatan yang tidak akan pernah usai: mewajibkan anggota terus menerus berada dalam majlis MTA.

\section{Terbentuknya Keterikatan Sosial (Social Belonging)}

MTA memiliki sistem keterikatan sosial yang cukup ampuh menjaga pengikutnya mampu bertahan dalam gerakan. Keterikatan sosial muncul melalui proses interaksi antara ajaran dalam gerakan dan tindakan antar anggota MTA sebagai satu kelompok yang terikat dalam organisasi. Keterikatan sosial ini membentuk semacam "tempat yang nyaman" di tengah resitensi masyarakat atas perilaku keagamaan mereka yang dianggap ekstrem karena menolak ritual desa dan tradisi lokal.

Keterikatan sosial dapat dilihat dari istilah keanggotaan dalam MTA yang disebut warga. Melalui pengajian, keanggotaan MTA disematkan dengan diberlakukannya absensi bagi para pengikutnya. Ini berarti pengajian adalah peneguhan keanggotaan bagi warganya. Di sisi lain, keanggotaan ditandai dari penolakan warga MTA terhadap tradisi lokal berupa ketidakhadiran dan kritik mereka terhadap ritual-ritual desa. Dengan sistem jaringan dan struktur yang kuat, istilah warga inilah yang menghubungkan keanggotaan MTA dalam satu organisasi besar di seluruh nusantara.

Identifikasi yang melekat pada warga MTA membentuk sistem keterikatan sosial. Terdapat tiga struktur sebagai bangunan keterikatan sosial. ${ }^{16}$ Pertama, attachment yakni apa yang melekat dalam diri seseorang sebagai bagian dari keanggotaan kolektif. Jika ini diaplikasikan dalam MTA, maka personal attachment berarti warga MTA adalah orang-orang yang maos atau mengaji. Narasi "orang yang mengaji” menjadi bermakna ketika dihadapkan dengan "yang tidak mengaji". Mengaji secara simbolik adalah sebagai pembeda antara mereka dengan kelompok di luar MTA yang tidak mengaji. Mereka yang tidak mengaji dianggap tidak tahu ilmu agama.

Kelompok ini dipersatukan dalam frame keyakinan, yakni keyakinan akan keselamatan dengan mengaji, memahami, dan

\footnotetext{
${ }^{16}$ Gabriel Pollini, "Social Belonging," dalam Edgar F Borgatta (ed.), Encyclopedia of Sociology: Second Edition Vol 4 (USA: MacMillan Reference, 2000), 2632-2635.
} 
mengamalkan Alquran dan Sunnah. Belief attachment atau kepercayaan yang mengikat mereka tampak dari istilah-istilah semisal "sang pencerah" dan "Islam itu agama yang asing". Dari sini, ketika pertentangan dengan kelompok tradisionalis semakin kuat, maka attachment antar anggota semakin kuat juga. Wacana pertentangan itu terus mereka produksi melalui pengajian dan diperkuat dengan memberi ajakan untuk tetap istiqamah di jalan yang benar.

Kedua, loyalitas, yang berarti mengedepankan kelompoknya daripada kepentingan pribadi. Loyalitas dapat dibuktikan dengan kredo warga MTA, "mengaji tidak boleh kalah dengan yang lain." Loyalitas erat kaitannya dengan kesetiaan seseorang, yang mengharuskan sikap mental selalu berada bersama kelompok.

Ketiga, solidaritas yang menekankan tanggung jawab seseorang dalam perannya sebagai bagian tidak terpisahkan dari kelompok. Solidaritas dalam MTA diarahkan untuk saling membantu sesama warga MTA, dengan adanya uang kas dan sumbangan sosial. Dari rasa solidaritas itu, MTA mampu menciptakan shelter atau perlindungan sosial kepada warga MTA. Ini yang membuat warga tidak harus kehilangan kehidupan sosialnya. Prinsip saling tolong menolong (sambatan) dan kesetaraan (pada-pada) yang menjadi ciri khas masyarakat desa tidak perlu tercerabut.

Solidaritas di atas dibentuk tidak hanya oleh ajaran tentang hubungan antar warga MTA sebagai saudara yang diikat oleh iman, namun juga oleh adanya jaminan sosial di kalangan mereka. Saling tolong-menolong dan kesetaraan antar warga juga ditunjukkan dalam keseharian mereka dalam bentuk uang kas sosial, yang dipergunakan untuk membantu sesama warga. Jika ada warga MTA yang sakit, misalnya, maka uang kas yang mereka kumpulkan disalurkan kepada warga itu untuk membantu meringankan biaya pengobatan. Selain uang kas, terdapat juga iuran untuk meringankan anggota menghadiri pengajian. Singkatnya, melalui prinsip solidaritas terbentuk praktik sosial yang memberi jaminan antar warga MTA sehingga mereka bisa bertahan.

\section{Komodifikasi Agama dalam MTA}

Ajaran dan praktik gerakan MTA seperti ajaran 
keseselamatan, imamah dan Jemaah, serta pengajian terbukti efektif dalam membentuk sistem keterikatan sosial (social belonging). Hal ini dibuktikan dengan munculnya identitas sosial, loyalitas, dan solidaritas antar anggota. Selain itu daya tarik lainnya adalah kharisma pemimpin MTA yang ada pada diri Ahmad Sukino, sesuatu yang bisa memobilisasi warga untuk terus mengikuti pengajian di majlis MTA. Dari pengajian itulah doktrin "jihad harta" ditanamkan. Organisasi MTA secara gamblang mengungkapkan bahwa sumber dana gerakan yang paling utama berdasarkan iuran pengikutnya. Dari sini, tumbuhlah apa yang disebut sebagai komodifikasi agama.

Komodifikasi agama secara umum diartikan sebagai: menjadikan nilai-nilai agama yang bukan barang komoditas menjadi sesuatu yang menuntut adanya komoditas yang dipertukarkan (exchange). Kitiarsa mengungkapkan bahwa komodifikasi agama mengandaikan agama menjadi dua hal: agama sebagai komoditas dan agama sebagai media pertukaran dalam pasar spiritual. ${ }^{17}$ Mengartikulasikan Kitiarsa, dalam MTA terdapat dua hal yang mendukung proses komodifikasi ini, yakni komoditas dan pasar. Pertama, komoditas yang berarti terdapat produk yang "dijual" oleh MTA, seperti koperasi simpan-pinjam dan koperasi penyedia kebutuhan sehari-hari di bawah CV Al Abrar. Dengan simpanpinjam, warga MTA dapat memperoleh modal untuk mengembangkan kehidupan ekonominya. MTA juga mendirikan usaha koperasi yang menyediakan kebutuhan sehari-hari bagi warga dan memproduksi air mineral, kaus, payung, dan barang lainnya.

Di samping koperasi, CV Al Abrar juga memilik penerbitan. Perusahaan ini mencetak berbagai brosur pengajian, majalah bulanan (bernama Respon), dan buku-buku pelajaran agama seperti panduan salat, tafsir Alquran, dan VCD atau MP3 ceramah-ceramah agama. Seluruh produk penerbitan menjadi komoditas bagi MTA untuk menambah pemasukan ekonomi. Brosur yang dikeluarkan setiap pengajian minggu pagi, hari jumat, maupun kegiatan MTA lainnya memang diberikan cuma-Cuma, tapi disediakan kotak infak untuk mengganti biaya cetak. Berdasar

\footnotetext{
17 Pattana Kitiarsa, "Sociology of Religious Commodification," dalam Turner (ed.), The New Blackewell Companion to Sociology of Religion. (UK: Blackwell, 2010), 565.
} 
pengamatan di lapangan, biaya cetak brosur tercukupi oleh jumlah infak yang diterima. Penjualan materi-materi pelajaran agama tidak dapat dari paradigm MTA akan pentingnya mempelajari ilmu agama.

Selain produk-produk di atas, MTA melalui doktrin jihad hartanya, terbukti cukup ampuh menghimpun dana sukarela anggota. Mulai dari tingkat cabang, pemasukan dari donasi zakat, infak, dan sedekah yang dikumpulkan oleh warga setiap minggu, dicatat dan disetorkan ke pimpinan pusat MTA. Pemasukan yang didapat tidak pasti dalam setiap minggu, karena MTA hanya memberikan himbauan moral kepada warga untuk menyumbangkan sebagian hasil kerja untuk agama. Kontribusi cabang untuk MTA pusat lainnya dapat dilihat dari infak kolektif cabang untuk mengganti biaya cetak brosur dan sejenisnya. Selain itu, cabang secara kolektif juga berlangganan majalah dan membeli buku-buku pelajaran agama MTA. Seorang warga MTA mengaku bahwa ia pernah menyumbangkan sebesar sepuluh juta rupiah sebagai infak untuk membantu pembangunan gedung MTA.

Pengajian di gedung MTA dapat dikategorikan sebagai "pasar spiritual", karena di sanalah transaksi paling massif antara warga dengan organisasi MTA dilakukan. Dari situlah penanaman doktrin "jihad harta” ditanamkan bagi warga MTA. Maka tidak heran, saat Pengajian Ahad Pagi, misalnya, banyak sekali kotak infak disediakan denga peruntukan berbeda-beda: di pintu masuk ada kotak infak kebersihan dan keamanan sandal; di dalam ruang pertemuan ada kotak infak pengajian, kotak infak TV dan radio MTA, infak sosial, infak pondok pesantren MTA, dan kotak infak lainnya. Jihad harta termasuk anjuran zakat agar didonasikan sebesar $2.5 \%$ dari total pendapatan, tanpa harus diakumulasikan setiap tahunnya

Pengajian Ahad Pagi dan pengajian mingguan membuat MTA terkenal, karena ceramah Al-Ustad Ahmad Sukino disiarkan di radio. Hal ini menjadi semacam iklan yang mengundang masyarakat luas yang haus akan ilmu agama untuk hadir. Selanjutnya, mereka menjadi "supermarket” bagi MTA. Di momen inilah produk-produk MTA (mulai dari buku, brosur, CD, dan marchendise MTA lainnya dijual. Massa yang hadir pada setiap Pengajian Minggu Pagi bisa mencapai kurang lebih 5000 hingga 6000 orang. 


\section{Penutup}

Banyaknya resistensi atau penentangan terhadap MTA tidak menyurutkan gerak organisasi yang bermarkas di Surakarta ini. Mereka justru mengolah konflik sedemikian rupa untuk memperkuat loyalitas dan solidaritas anggota. Narasi yang dimunculkan terkait adanya penolakan, pembakaran majlis MTA, pengucilan dari masyarakat adalah sebagai berikut: warga MTA merupakan kelompok kecil masyarakat pejuang kebenaran dengan dasar perjuangan "Islam itu asing dan akan kembali asing." Narasi itulah yang selalu mereka produksi untuk memperteguh identitas warga MTA sebagai kelompok Islam yang berjuang membawa keselamatan. Selain itu, MTA juga menekankan terbentuknya solidaritas dengan saling membantu antar warga. Solidaritas ini menjadikan MTA sebagai "tempat yang nyaman" bagi anggota di tengah maraknya penolakan terhadap mereka. Pengajian dan majlis MTA berhasil mengkonstruksi identitas kolektif, membentuk loyalitas dan solidaritas antar anggota. Dengan demikian, proses memperoleh pendanaan dan komodifikasi agama menjadi lebih mudah.

\section{Daftar Pustaka}

Asif, Muhammad. "Sejarah Tafsir MTA (Majlis Tafsir AlQur'an)." Al-Itqan: Jurnal Studi Al-qur'an. 2015.

Haryanto, Joko Tri. "Relationship, Transformation and Adaptation of the Traditionalists Against Puritanism in Surakarta Indonesia." Analisa: Journal of Social Science and Religion, Vol 22, No 2. 2015.

Jinan, Mutahharun. "Penetrasi Islam Puritan di Pedesaan: Kajian tentang Pola Kepengikutan Warga Majlis Tafsir AlQur'an." Profetika: Jurnal Studi Islam, 14, 2. 2013.

Kitiarsa, Pattana. "Sociology of Religious Commodification," dalam Turner, Bryan (ed.). The New Blackwell Companion to Sociology of Religion. UK: Blackwell, 2010.

Kitiarsa, Pattana. Religious Commodifications in Asia: Marketing God. New York: Routledge, 2008.

Laili, Nihlatul. "Majlis Tafsir Al-Qur'an (MTA) vs Nahdlatul Ulama (NU): Konflik Sosial Keagamaan Masyarakat Islam Jawa Tengah Tahun 1990-2013. Yogyakarta: Disertasi doktoral, Universitas Gadjah Mada, 2016. 
Ma'rifah, Indriyani dan Asroni, Ahmad. "Berebut Ladang Dakwah pada Masyarakat Muslim Jawa: Studi Kasus terhadap Konflik Majelis Tafsir Al-Qur'an (MTA) dan Nahdlatul Ulama (NU) di Kabupaten Purworejo. Jurnal Dakwah, Vol. 14, No. 2. 2016.

McAdam, Doug et al. Comparative Perspectives on Social Movements: Political Opportunities, Mobilizing Structures, and Cultural Framings. Cambridge: Cambridge University Press, 1996.

Muhsin, Ilyya dan Ghufron, Muhammad. "Geliat Puritanisme Islam di Indonesia: Menyibak Tabir di Balik Gerakan Majelis Tafsir Al-Qur'an (MTA) dalam Perspektif Sosiologis." INFERENSI: Jurnal Penelitian Sosial Keagamaan, Vol 12, No 1. 2018.

Pollini, Gabriel. "Social Belonging," dalam Borgatta, F Edgar (ed.). Encyclopedia of Sociology. USA: MacMillan Reverences, 2000.

Qusthalaani, Imam. "Analisis Penafsiran Ayat Hiisab Rukyat Menurut Majlis Tafsir Al-Qur'an." Semarang: Disertasi doktoral-UIN Walisongo, 2016.

Suryadilaga, M. Alfatih. "Majlis Tafsir Al-Qur'an dan Keberagamaan di Indonesia: Studi tentang Peran dan Kedudukan Hadis Menurut MTA." Masyarakat Indonesia, 41(1), (2016).

Tamney, Joseph. "Moderization and Religious Purification: Islam in Indonesia." Review of Religious Reseach, Vol 22, No 2. 1980.

Ul Haq, Fajar Riza. "Islam Sebagai Gerakan Sosial, Studi atas Jama'ah Al-Islam Gumuk Surakarta." Yogyakarta: MA TesisCRCS UGM, 2008.

Widodo. 'Yayasan Majlis Tafsir Al-Qur'an (MTA) Surakarta Tahun 1972-1998: Studi Tentang Gerakan Modern Islam di Surakarta. Surakarta: Skripsi-Fakultas Sastra Universitas Sebelas Maret Surakarta, 1998. 